УДК 398

DOI: $10.21779 / 2542-0313-2016-31-3-78-86$

\title{
Г.А. Мудунова
}

\section{Свадебная обрядовая поэзия лакцев}

Дагестанский государственный университет; Россия, 367001, 2. Махачкала, ул. М. Гаджиева, 43a; patimakardashova@mail.ru

В статье рассматривается свадебная обрядовая поэзия лакцев. Некоторые старые свадебные песни - веселые, красочные - продолжают жить в новом обряде свадьбы. Другие существуют в качестве художественного наследия в профессиональном искусстве и художественной самодеятельности. Третьи, оторвавшись от своей исчезнувшей основы - традиционного обряда, перешли в народный репертуар в качестве необрядовых лирических песен. Итак, в свадебной обрядовой поэзии лакцев в прошлом бытовали жанры свадебных причитаний, величальных песен, песен-наставлений (советов), шуточных (корильных) песен. В настоящее время сохранившимся жанром можно считать жанр величальных песен. Другие жанры изменили свои функции, сменили жанровую принадлежность, а частью перестали существовать.

Ключевые слова: лакский фольклор, свадебная обрядовая поэзия.

UDC 398

DOI: $10.21779 / 2542-0313-2016-31-3-78-86$

\section{Ritual wedding poetry of the Laks}

\section{H.A. Mudunova}

Dagestan State University; Russia, 367001, Makhachkala, Gadzhiyev st., 43a; patimakardashova@mail.ru

The article is devoted to the wedding ceremonial poetry of the Laks. Some ancient wedding songs - funny and colorful - continue to live in the new rite of the wedding. Some are in the quality of the artistic heritage in the professional art and amateur art activities. Some distanced from their missing essentials - the traditional ceremony - have become the part of folk repertoire as non-lyrical songs. Thus, in the past genres of wedding laments, cheering songs and songs of instruction (tips), comic (koralnik) songs existed in the wedding ceremonial poetry of the Laks. At present, the only preserved genre is a genre of cheering songs. Other genres have changed their function and their type and partially disappeared.

Keyword: lak folklore, ritual wedding poetry.

Нельзя рассматривать фольклор как явление с одинаковыми законами для всех его жанров. Перед нами встает достаточно сложная и в то же время представляющая большой научный интерес задача - выявление жанровой принадлежности и своеобразия разновидностей свадебной обрядовой поэзии. На пути решения данной проблемы встречаются многочисленные трудности. Одна из них - отсутствие древних записей фольклорных произведений. В наличии у нас лишь записи советского времени, относящиеся в основном к 30-м годам прошлого столетия. Нет сомнений, что существующие записи в какой-то степени сохранили для нас и те произведения, 
которые возникли в более ранние эпохи. Однако все фольклорные произведения в современном исполнении приобретали во многом новое звучание: в них что-то исключается, что-то добавляется, что-то изменяется. Изменения в фольклорных текстах неизбежны потому, что тексты сохраняются в различных условиях, а при переходе в новые исторические условия происходит определенная трансформация произведения, которое тем самым приобретает новый характер.

Важнейшая теоретическая проблема - выяснение специфики различных фольклорных жанров, их определение и классификация. Исторический путь любого фольклорного жанра в целом складывается по своим особым законам. Теоретические обобщения, помогающие понять метод фольклора как особого способа художественного изображения действительности, могут быть сделаны только после решения конкретных вопросов, связанных с происхождением жанров, их бытованием и спецификой фольклорной эстетики в системе каждого из них. Проблема изучения жанра на современном этапе развития фольклористики становится одной из основных.

Свадебный обряд лакцев, как и у всех народов Дагестана, состоял из сговора, сватовства и собственно свадьбы. Но необходимо отметить, что существовали и предсвадебный, и послесвадебный циклы свадебной игры. Обычно юноша, влюбленный в девушку, каким-то способом давал знать об этом своим родителям. Это делалось через тетю, сестру или соседку.

Отец юноши, узнав о любви сына к определенной девушке, приглашал близких и советовался с ними, можно ли просить руки дочери такого-то человека. По окончании совета выбирали одну женщину, которая отправлялась в дом родителей невесты и давала знать, что она послана таким-то. На следующий день отец невесты приглашал своих близких и советовался с ними; и только после совета давали слово - свое согласие или отказ. Отказывали под благовидным предлогом.

В начале посылали женщину, чаще как бы «полулегально» и только к матери невесты, затем вполне официально посылался мужчина с близкими юноше женщинами с подарками.

Приличия требовали, чтобы во время первого визита отец девушки отвечал уклончиво, обещал посоветоваться с родственниками, старшими братьями или ссылался на молодость дочери, неподготовленность ее к выполнению сложных обязанностей жены. «Родители невесты, - писал Абдулла Омаров о лакцах, - стараются не уронить своего достоинства и никогда не изъявляют сразу своего согласия... Таким образом, сват ходит несколько недель за ответом» [14].

Акт обручения «махъ булаву» («дать слово») отмечался в торжественной обстановке с приглашением всех родственников, а нередко и всех односельчан.

У многих народов для скрепления принятых обязательств хотя и устного договора родителям невесты вручалась какая-нибудь ценная вещь (шелковый платок, кольцо, браслет, деньги), которая называлась «аьш».

Часто от сватовства до свадьбы проходило месяцев шесть, иногда 1-2 года. Срок нередко зависел от экономического положения семьи жениха: бывали случаи, когда свадьба откладывалась на несколько лет. Одной из причин этого могло быть и несовершеннолетие детей. Все время до свадьбы семья жениха обязана была окружать невесту вниманием, делать ей периодически, особенно по праздникам, подарки, которые иногда были очень обременительны, а в ряде случаев должны были даже обеспечивать ее питанием на все это время.

Поведение засватанной менялось: она попадала в определенную зависимость от 
семьи жениха. У кумыков, дербентских азербайджанцев, табасаранцев и некоторых других народов после обручения до специального разрешения со стороны родни жениха невеста должна была сидеть дома, избегать встреч с родственниками юноши.

В Нагорном Дагестане засватанная девушка, как и любая горянка, держалась более свободно. Она не была так изолирована от семьи жениха, как девушка из плоскостной зоны. У лакцев она нередко участвовала даже в полевых работах семьи своего будущего мужа, жених мог присутствовать при этом, помогая ей, например, связывать сжатый хлеб в снопы, но в присутствии людей молодые строго соблюдали установленный этикет, держались по отношению друг к другу официально [15, с. 37]. И у других народов жених мог изредка встречать свою невесту, но в тайне от родителей и братьев девушки. У лакцев «невеста по обычаю должна избегать всяких встреч с женихом в присутствии других, но зато всегда найдется какая-нибудь старуха по соседству, которая легко устраивала свидания для молодых» [15, с. 38], - писал А. Омаров.

Самой торжественной и зрелищной частью свадьбы являлась процессия увода невесты в дом жениха. Это было центральным актом свадебного сценария. Невесту приводили пешком, а в ряде обществ - на лошади.

Обычно свадьбу справляли осенью после завершения полевых работ. На свадьбу приглашались все родственники, а в малых аулах - все односельчане. Они приходили с «ххунча» (с дарами). Невесту в дом жениха сопровождали ее подруги и «архІалщар» («женщина рядом»). Эта женщина отвечала за девушку, объяснила ей обязанности жены.

На всем пути следования свадебной процессии девушки пели величальные песни. Особого уважения и величания требовал свадебный ритуал по отношению к невесте. В разговоре и в песнях она у лакцев называется «жалин». В ряде песен невеста и жених названы детьми солнца и луны. Солнце, по мифологическим представлениям лакцев, это прекрасноликий юноша, озаряющий весь мир и излучающий тепло, луна - это круглолицая красавица.

В поэтике величальных песен преобладают эпитеты, образованные от названий драгоценных металлов, камней: «золотые ворота», «серебряные двери» и др. У жениха «серебряное оружие», у невесты «большой коралловый сундук». Порою у жениха «рыжий скакун», у невесты - «рыжая корова». По отношению к серебру используется эпитет «белое серебро», к золоту - «красное золото».

$\mathrm{Bce}$, что связано с невестой, озарено светлыми тонами. Она идет по жемчужным улицам, везде горят костры. В величальных песнях идеализируется все: и внешность, и наряд девушки. Она красавица, выросла в знатном доме, у нее многочисленная родня, она обладает многими драгоценностями. Под ноги ей постелют драгоценный ковер, она поднимется по мраморным ступенькам на верхний этаж, в ее гостиной кругом зеркала, она будет сидеть на постели из хлопка.

Свадебные обрядовые песни имеют различия в тематике, особенностях поэтики и музыкальном языке. В состав свадебных песен входят не только песни, имеющие музыкально-поэтические черты, общие для лирических обрядовых песен, но и песни свадебно-величальные, поэтика которых близка к поэтике календарных величальных песен. Песня выражала отношение не только жениха и невесты, но и всего рода к этому важному событию в жизни. В свадебных песнях рядом с основными героями свадебного действа - женихом и невестой - встречаются и другие участники этого торжества.

Большинство лакских свадебных песен исполнялось хором. Песни не имели законченного стройного сюжета, но содержали сюжетные мотивы и ситуации, интонации песен носили восторженный характер.

Своеобразным жанром свадебной поэзии представляются шуточные песни. Эти

80 Вестник Дагестанского государственного университета.

Серия 2. Гуманитарные науки. 2016. Том. 31. Вып. 3 
песни в русской свадебной поэзии получили название «корильные». Величальные песни гостям на русской свадьбе должны были оплачиваться величаемым персонажем, который давал исполнителям величальных песен мелкие деньги или конфеты. Если же он оказывался скупым, то в «корильных» песнях зло высмеивали его, издевались над его внешностью, нарядом, лицом, семьей и т. д.

В некоторых местах существовали «корильные» песни, обращенные и к новобрачной. Это бывало в тех случаях, когда она была привезена из другой деревни без предварительного сватовства ее мужа в родной деревне. Такие песни пели девушкиодносельчанки жениха, которые были обижены на жениха за пренебрежение к ним. «Корильные» песни по отношению к новобрачной назывались в народе «гордены», ибо высмеивали гордость, чванливость и другие качества, приписываемые ей [21].

В свадебной поэзии лакцев особо надо отметить укоры, выражаемые в песенной форме со стороны невесты и жениха. Когда родственники жениха приходили за невестой, девушки этой свиты пели:
Жул наврузбагнал бутта
Отец нашего жениха
Хъуни къатрал заллури.
Хозяин большого дворца.
Зул жалиндалул буттал
Отец вашей невесты
ЧІиви чІалъаь чІалай бур.
Имеет лишь маленький дом.
Жул наврузбагнал къатта
Дом нашего жениха
Утта кучалий буссар.
Расположен на широкой улице.
Зул жалиндалул къатри
Дом вашей невесты
Кьума кІичІирттаву дур.
Находится на узкой улице.

Можно сказать, что укор звучит в юмористическом русле. Каждая сторона хвалит достоинства, которыми обладают жених или невеста, родственники жениха считают себя лучше. В свою очередь сторона невесты старается в ответ выразить свое превосходство над стороной жениха:

Жул чІалъаь чІивинугу,

ЧІан къатри гьартассари, КІичІиртту къуманугу, Хъуни гьивурду гьайссар.

Зул наврузбагнал буттал

Хъуни къатри духьурча,

Хъун къатлул заллу хьунсса,

Жулгу хІурульэн буссар.

Зул наврузбагнал буттал

Утта куча бухьурча,

Миккун хьулун дачин дан

Аьравалтту жулгу дур.

\section{Часто в свадебных песнях, распеваемых одной стороной,}

Хоть дом маленький у нас,

Зато широки полы (у нас),

Хотя улицы узки,

Большие поклажи проходят.

Если у отца вашего жениха

Большой дворец,

У нас имеется гурия,

Которая станет хозяйкой (в нем).

Если у отца вашего жениха

Широкая улица,

Чтобы подогнать к воротам,

У нас арбы имеются.

менно упрек и ответ на этот упрек.

Вот пример такой свадебной песни:

\section{Вабабай!}

Илхъилуву хъахъи чу, гьалилай.

Зулгу оьрчІал бухьурча, гьалилай,

Газулуву ттуру оьл, гьалилай,

Жулгу душнил буссари, гьалилай.

Гьали, гьали, гьалилай, гьалилай

Жулгу душнил буссари, гьалилай!

Вабабай!

\section{Вабабай!}

Если в табуне рыжий конь, гьалилай.

Имеется у вашего юноши, гьалилай,

В стаде рыжая корова, гьалилай,

У нашей девушки имеется, гьалилай.

Гьали, гьали, гьалилай, гьалилай

У нашей девушки имеется, гьалилай!

Вабабай! 
Мюрай марцІ арцул ярагъ, гьалилай, Зулгу оьрчІал бухьурча, гьалилай, Буцурдух хъун магьаржа, гьалилай, Жулгу душнил буссари, гьалилай, Гьали, гьали, гьалилай, гьалилай, Жулгу душнил буссари, гьалилай! [5].
Если на гвозде оружие из чистого серебра, гьалилай,

У вашего юноши имеется, гьалилай,

За горкой постели большой сундук, гьалилай, У нашей девушки имеется, гьалилай,

Гьали, гьали, гьалилай, гьалилай.

У нашей девушки имеется, гьалилай!

Шуточные песни большей частью бывали адресованы женщине, сопровождавшей невесту. Она являлась советчицей, наставницей невесты и постоянно находилась с ней. Она оберегала невесту от всевозможных неприятностей, от нечистой силы, дурного сглаза, совершала с этой целью предохранительные магические действия.

В песнях лезгин, адресованных женщине - наставнице невесты, вырисовывался отрицательный образ. Невесту могла сопровождать молодая красивая наставница Нииб (Енге), но какими бы достоинствами в каждом конкретном случае не обладала спутница невесты, ей не избежать традиционных насмешек. Она вскормлена ослиным молоком, толста, как свинья, необычайно прожорлива (в песне, обращаясь к слушателям, восклицают: «Хватит ли полных тазов плова и халвы?»), зубы у нее - клыки... Ей желают сломать ногу и получить болезнь сердца... [2].

В лакских песнях о женщине-наставнице невесты говорится много отрицательного как бы в шутку:

АрхІалщар аьркку дури,

Цурда дарвагза хханссар,

Ххяли кьацІ хъунмасса бур -

Щаллунма бурки гьанссар.

Кару къазихьру хханссар,

Ччанну ччиннуксса бури,

БакІрал ялу кьаму бур

Яру тІясру хханссар.

У лакцев наставницей была сестра матери, жена дяди или старшего брата. Это близкая женщина, которая несла особенную ответственность за охрану невесты от враждебных сил. Иногда наставницами, как и у кумыков, были две женщины: одна старая, другая молодая.

Свадебные лирические песни соотносились с обрядом довольно свободно. Песни во многих случаях являлись как бы украшающими вставными эпизодами. Конечно, были песни, по своему содержанию, а также в силу традиции, издавна закрепленные за определенными разделами свадебного сценария - приходом за невестой, прощанием с домом, отъездом к дому жениха, шествием по улице и пр. Но другие - и таких было немало, особенно среди песен коротеньких - свободно пелись в разные моменты свадебного обряда.

Песня должна была показать отношение не только жениха и невесты, но и всего рода к тому, что совершалось, поскольку свадьба была важным событием - в семейный коллектив принимался новый член. Поэтому в лирических песнях свадебного цикла рядом с основными героями - «молодыми» - появляются и другие участники обряда: родители, подруги невесты, свадебные гости [16].

Лирические свадебные песни - поэтизированные рассказы о любви молодой пары, об устройстве молодой семьи, об отношении к молодоженам окружающих.

В песне отражена праздничная, красочная, радостная сторона жизни, в которой так или иначе участвовали все, кто был близок молодоженам.

Эмоциональный тон у лирической свадебной песни богатый и разнообразный. В 
ней много торжественного, светлого, нарядного. Большинство песен исполнялось хором. Лирическая свадебная песня - это широкое и обобщенное отражение обряда в его основных тематических преломлениях. Поэтическая речь песни течет плавно и содержит в себе отдельные сюжетные мотивы и ситуации; интонация песни спокойная, стиль изложения объективен, логичен и, как правило, основывается на описательных и повествовательных элементах.

Импровизационный момент в песне присутствует редко. Текст - в том или ином локальном варианте - бывал закреплен традицией и заранее известен исполнителям; в общей его композиции не могло возникнуть ничего случайного, неожиданного; отдельные сюжетные мотивы чаще всего закруглялись до степени самостоятельного, хотя и небольшого повествования.

Сила художественного воздействия была в устойчивости, типичности и яркости устоявшихся традиционных образов и поэтических приемов, в их сюжетности, компактности, в единстве и целостности поэтического замысла, лежащего в основе песни. Поэтому лирическая народная песня, в частности свадебного тематического цикла, всегда была произведением искусства отточенного, коллективного, отработанного поколениями певцов.

Ритмическая структура свадебной песни достаточно четка. Напев песни мелодически развит, хоровое исполнение окружает основную мелодию подголосками и создает богатое, нарядное, праздничное звучание.

У многих лирических свадебных песен лакцев строка украшается повторами и припевами, построение которых разнообразно. Иногда функцию повтора выполняет последнее слово стиха.

Повторение слова, завершающего стих, может сочетаться с восклицанием, семантически никак с текстом не связанным.

Но наиболее часты случаи, когда в припев берется просто украшающая звукопись, нарядные словесные завитки (гьалилай, ва гъали, гьали и т. д.) [18].

В свадебных песнях лакцев, как, например, и у адыгов, весь быт и его детали приукрашены, идеализированы: черной работы невеста не выполняет, наоборот, она избалована, изнежена, одета нарядно, получает богатые подарки, сладко ест и пьет [13].

В свадебной песне дается идеализация. Характерные черты природного облика конкретных воспеваемых персонажей строятся на описаниях богатых, нарядных костюмов.

Центральные образы свадебной лирики - невеста и жених. Невеста беззащитна, малосильна, еще молода, незрела. Она жалобно отстаивает свою относительную свободу в доме родителей, она еще не пригодна в качестве работницы в новой семье. Она скромная куропатка, голубка, птица без крыльев. Эти образы, издавна привычные в свадебной поэзии, обозначают невинность, молодость и слабость.

Рядом с невестой жених - самовластный сокол, отбивающий куропатку; охотник, ловящий серну, оленя, он купец, выторговавший за большие богатства голубку, обладатель боевого грозного коня.

Внешняя изобразительность создается различными приемами традиционной народной поэтики, которые органично и тесно вплетаются в художественную ткань текста. Одним из существенных приемов является эпитет.

В тексты свадебной лирики отбираются обычно наиболее нарядные, блестящие и красочные эпитеты. Вокруг невесты в свадебных песнях все сверкает золотом, серебром, жемчугами. У жениха золотое, серебряное оружие, зеркала на всю стену, балконы 
стеклянные, постель ватная, пуховая.

Сравнения в их простейшей форме («я жила вольно в доме отца, как куропатка в поле», «попала в капкан охотника, как голубка в силок») употребляются относительно мало.

Чаще встречаются метафоры и отдельные метафорические уподобления. О невесте говорят как о деревце, которому не дали вырасти, как о яблоке, которому не суждено вызреть, как о куропатке, которой обломали крылья, как о цветке, побитом морозом, и т. Д.

Свадебная лирика пронизана символикой. Символы счастья - свет, блеск, музыка, расцветающие деревья, веселые птицы. Для символического изображения брака и организации семьи в народной поэтике имеются устоявшиеся выражения: сорвать цветок, построить дом, свить гнездо, схватить оленя, серну и др. Самим народом вся эта символика, по-видимому, уже давно перестала осмысливаться, ее корни уходят слишком глубоко в прошлое.

«Наиболее ранними в обрядовой поэтике были символы, возникшие на основе мифологических представлений, относящихся к древней стадии доисторического периода жизни народа: символы небесных светил и явлений» [4]. В лакских песнях жених и невеста названы детьми Солнца и Луны. В свадебной поэзии встречается много художественных образов, относящихся к растениям, животным, птицам, которые могли возникнуть в представлении народа именно на той стадии экономического и общественного развития, когда в общих чертах оформился и их свадебный обряд, т. е. на стадии окончательного разложения родового строя, в условиях земледельческого труда, дополнением к которому служила охота.

Традиционный обряд народной свадьбы стал в аулах заметно деградировать в конце XIX века и начале XX столетия [3]. С распадом основной обрядовой схемы (выпадением отдельных обрядовых эпизодов, упрощением и сокращением их, перестановкой внутри обряда и т. п.) начинает меняться и связь свадебного действа с песнями. Прежде всего это сказалось на причете.

Узко субъективные образы, не имевшие отношения ко всему свадебному коллективу, постепенно исчезали из общей системы поэтики свадебного фольклора и забывались. Лишенный по своим жанровым особенностям возможности жить в качестве художественного наследия, свадебный причет под воздействием новых бытовых и общественных условий навсегда ушел из устной народной поэзии и в наше время продолжает свою жизнь только как памятник прошлого в воспоминаниях некоторых пожилых людей.

В последовательном исчезновении песен из обряда тоже имелась своя логика. Корпус народного свадебного действа издревле опирался на сочетание трех факторов: пережитки историко-правовые, пережитки магии оберегающей и магии продуцирующей. Раньше всего (и, по-видимому, уже давно) начали исчезать из обряда пережитки историко-правовые, т. е. обрядовые детали, говорившие о купле-продаже невесты, о власти мужа-хозяина над женой, о бесправии и покорности молодой в новой семье и Т. п.

Соответственно начали прежде всего забываться и песни на эти темы как не оправдавшие себя в быту, противоречащие этому быту.

Песни, связанные с магическими пережитками, стали особенно заметно забываться в последние десятилетия в связи с изменившимся отношением к древним суевериям. В свадебном действе давно уже исчезли обрядовые детали, связанные с верой в порчу, обереги и т. п. Соответственно исчез и связанный с ними фольклор. Обряды магии продуцирующей, выполнение таких традиционных действий, как, например, осыпание мо-

84 Вестник Дагестанского государственного университета.

Серия 2. Гуманитарные науки. 2016. Том. 31. Вып. 3 
лодых зерном или горохом, благословение на шкуре животного, целый ряд присказок и песен эротического характера, связанных с заклинанием плодородия, превратились в шутливую игру. Песни уходили вместе с отмиравшими пережиточными обрядовыми деталями. Песни о радостной любви, семейном благополучии, счастье оказались значительно более жизнеспособными.

Некоторые старые свадебные песни - веселые, красочные - продолжают жить в новом обряде свадьбы. Другие существуют в качестве художественного наследия в профессиональном искусстве и художественной самодеятельности. Третьи, оторвавшись от своей исчезнувшей основы - традиционного обряда, перешли в народный репертуар в качестве необрядовых лирических песен.

Итак, в свадебной обрядовой поэзии лакцев в прошлом бытовали жанры свадебных причитаний, величальных песен, песен-наставлений (советов), шуточных (корильных) песен. В настоящее время сохранившимся жанром можно считать жанр величальных песен. Другие жанры изменили свои функции, сменили жанровую принадлежность, а частью перестали существовать.

\section{Литература}

1. Абачараева М.М. Язык песенного фольклора лакцев: автореф. дис. ... канд. филол. наук. - Махачкала, 2013. - 22 с.

2. Вагабова Ф.И. К вопросу об особенностях лезгинской народной песни // Ученые записки. - Махачкала, 1964. - Вып. 3. - С. 77.

3. Гаджиева С.Ш. Семья и брак у народов Дагестана в XIX - начале XX в. - М.: Наука, 1985. - С. 6-7.

4. Колпакова Н.П. Лирика русской свадьбы. - Л., 1973. - С. 257.

5. Лакрал агьалинал балайрду // Лакские народные песни / подготовка текста, сост., предисловие и коммент. Х. Халилова. - Махачкала, 1970. - С. 22-23.

6. Мазанаев Ш.А. Агульская литература. - Махачкала: Дагкнигоиздат, 2008.

7. Мазанаев Ш.А., Базиева (Амаева) 3.М. Агульский фольклор. От устного народного творчества к литературе. - Махачкала, 2014.

8. Мазанаев Ш.А., Базиева З.А. Песенное творчество агулов. - Махачкала: ИПЦ ДГУ, 2011.

9. Мазанаев Ш.А. К вопросу о национальном своеобразии многоязычной литературы Дагестана // Вестник Дагестанского научного центра Российской академии образования. - 2013. - № 2. - С. 61-64.

10. Мазанаев Ш.А. Становление и развитие агульской литературы // Вестник Дагестанского государственного университета. - 2013. - Вып. 3. - С. 84-89.

11. Мудунова Г.А. Фольклорные мотивы в творчестве Абакара Мудунова // Проблемы истории, филологии, культуры. - 2014. - № 4 (46). - С. 253-256.

12. Мудунова Г.А. Фольклорные мотивы в творчестве Щазы Курклинской // Вестник Дагестанского государственного университета. Сер. 2: Гуманитарные науки. 2014. - Вып. 3. - С. 72-79.

13. Налиев 3.M. Адыги // Семейно-обрядовая поэзия народов Северного Кавказа. Махачкала, 1985.

14. Омаров А. Воспоминания муталима // ССКГ. Вып. 1: Этнографические очерки. - Тифлис, 1870.

15. Омаров А. Как живут лаки // ССКГ. Вып. 4: Этнографические очерки. - Тифлис, 1870. - С. 37-38. 
16. Хамищаева T.A. Осетины // Семейно-обрядовая поэзия народов Северного Кавказа. - Махачкала, 1985. - С. 128-129.

17. Халилов Х.М. Лирика народов Дагестана: взаимосвязи, типология и этническая специфика. - Махачкала, 2004.

18. Халилов Х.М. Народы Дагестана // Семейно-обрядовая поэзия народов Северного Кавказа. - Махачкала, 1985. - С. 48-49.

19. Чалаева П.Ш. Абдулла Омаров и его роль в развитии лакско-русских языковых контактов // Проблемы истории, филологии, культуры. - 2014. - № 4 (46). - С. 257 260.

20. Чалаева П.Ш. Роль П.К. Услара и его учеников в развитии лакско-русских языковых контактов // Мир науки, культуры, образования. - 2012. - № 2 (33). - С. 307 309.

21. Чердынская свадьба. - Пермь, 1969. - С. 11.

Поступила в редакичюю 22 октября 2016 г.

Received 22 October 2016 